and arts. They have made it possible to hold our annual meetings, and even in San Francisco. I deliberately say. that the old Code, as to the ethics of medical ideas outside of books, is a poor arrangement; when any new ideas (save as above) come, we are to close ourselves up like the box turtle and let them blow over us-we are not to encourage inventions that will benefit humanity (Elsberg's forceps)we are to wait until public opinion comes and kicks open our shell; and yet we can use antipyrin et id omne genus, swallowing our Code and all; we can blow up inventors for not patenting medical ideas when we have told them not to; we can as a medical association, advertise nostrums by the dozen to the world in the very number of the Joursal in which good Father Davis asks the question I am trying to answer. Is not this "mammon and dishonor?" For one, I am grateful to the Committee for what they have done so fearlessly and deftly ; I admire our venerable father's energy, point and force, and what $I$ have written here is simply on my own responsibility, declarative of my ideas in answer to the question frankly, plainly and honestly. I wish others would speak out their sentiments, pro or con, and then this vexatious matter could be settled and the AssociATION attend to work of which there is dying need and members are dying in need of, to-wit: The "new gospel of Materia Alimentaria."-(Joseph Jones, M.D., LL.D., New Orleans.)

I look forward to the time when any person qualified to practice medicine, and who calls himself simply a physician and surgeon with no sectarian title, can walk into the AMER ICAN MEdrCal Association to full-hearted membership and " not to doubtful disputations," and the Code will consist of the law of the eternal fitness of things which needs not man's arbitrary measurements, but does things rightly because complemented by the law of compensation, the executive of Justice.

E. Cutter, M.D.

\section{Medical Institutions of San Francisco.}

Sax Francisco, April 26, 1894.

To the Editor:-The American Medical Association will meet in San Francisco June 5 to 8. During the meeting the members will be cordially invited to visit the following institutions :

City and County Hospital, Potrero Avenue and 22d Street, contains 450 beds. Superintendent, F. H. Titus ; visiting surgeons, R. A. MeLean, C. N. Ellinwood and G. F. Shiels; visiting physicians, W. W. Kerr and J. O. Hirschfelder; oculists and aurists, W. E. Hopkins and Geo. Merritt ; visiting gynecologists, H. Kreutzmann and C. A. von Hoffmann.

St. Mary's Hospital, First and Bryant Streets, is conducted by the Sisters of Mercy. Visiting surgeon, A. T. Leonard; gynecologist, Luke Robinson; physicians, W. S. Thorne and M. J. Fottrell ; oculists, G. H. Powers and W. E. Hopkins.

German Hospital, 14th and Noe Streets, contains 200 beds. Visiting surgeon, J. F. Morse; ophthalmologist, A. Barkan; gynecologist, H. Kreutzmann; physician, Rudolph Baum.

French Hospital, Bryant Street near Sixth. Visiting surgeon, Dr. Bazan; physicians, J. D. de Chantreau and G. Gross ; oculist, K. Pischl.

St. Luke's Hospital, Valencia Street near 27th, contains 75 beds. Visiting surgeon, C. G. Kenyon; physicians, Washington Dodge, F. W. D'Evelyn and C. J. Burnham ; oculists, G. H. Powers and A. H. Voorhies; gynecologist, W. H. Mays.

Children's Hospital, 3700 California Street, contains 100 beds including the Maternity. Visiting physicians, Lucy M. F. Wanzer, Emma S. Merritt, Eảna R. Field, Mrs. C. B. Brown, Charles von Hoffmann, A. P. Woodward; oculist and aurist, W. E. Hopkins ; orthopedic surgeon, Harry M. Sherman.

California Woman's Hospital, 3118 Sacramento Street, $\begin{gathered}\text { The roads beyond Missour } \\ \text { about one and a half fares. }\end{gathered}$ contains 50 beds. Visiting surgeons, C. B. Brigham, 0.0 Burgess, W. Winterberg, C. Max Richter, Dudley Tait, L. L. Dorr; surgeon in charge, F. W. Vowinckel.

United States Marine-Hospital is situated in the Presidio Reservation on the banks of Mountain Lake, and is accessible by the Sacramento Street cars.

Another hospital is on the eve of completion, viz,: Lane Hospital, which will contain over one hundred beds; this has been erected by the writer at a cost of $\$ 150,000$ and has been presented by him to Cooper Medical College, thus giving this institution unsurpassed facilities for the work of medical education.

This pile of buildings, which is in conspicuous view to the traveler who enters the Golden Gate, together with the lands accompanying the gift, equals in value a half million of dollars, and has been presented as an offering to the Healing Art in its merciful service to suffering humanity.

The members of the Associatios will also have an opportunity of visiting the medical college erected and presented to the University of California by the late Dr. H.H. Toland. Some of the members will remember their visit to this institution during their sojourn here, twenty years ago, when they were given a reception there by the distinguished founder. The heart of Dr. Toland would have beat less exultantly on that occasion could he have foreseen that in less than twenty years there would be a movement on foot to sell and abandon the edifice which he had planned as an enduring monument to the name of Toland. And should history repeat itself, and the unpitying hand of ingratitude pull down the monument which otherwise will perpetuate the names of Lane and Cooper, then would the scene in heaven as painted by a modern Greek poet be realized, viz.: Benefaction and Gratitude as strangers did not recognize each other. in Heaven, since they had never met on earth. L. C. LaNe, M.D.

\section{ASSOCIATION NEWS.}

The Association Train will leave Chicago Monday, May 28, via Santa $\mathrm{Fe}$ R. R., Rio Grande Western, and Southern Pacific, for San Francisco via Denver, Colorado Springs, Leadville, Manitou, Glenwood Springs, Salt Lake, Ogden, Truckee and Sacramento. Returning, after the meeting, the train will pass through Sacramento and Northern California to Portland, thence east by way of the Northern Pacific R. R. to St. Paul. C. M. \& St. P. R. St. Paul to Chicago. A stop over at Yellowstone National Park for those who desire it has been arranged, and it has been understood that at several places on the journey there will be short stops. President Hibberd's party in a special car join the train at Chicago, and the St. Louis party are expected to join at Kansas City. From all points east and south, concentrating on this train should be effected at Chicago and St. Louis. For all information relating to this train, fares, etc., address J. M. Connell, 212 Clark st., Chicago, or any agent of Santa $\mathrm{Fe}$ line in other cities. Rates promised are the lowest excursion rates at time of departure.

This is the only route on which arrangements have been perfected by the Trustees.

Circular from Committee of Arrangements.-The American Medical Association will meet in San Francisco, June 5, 1894.

The trancontinental railroads have made favorable rates, viz: $\$ 65.50$ for round trip from all Missouri River points, which is one and one-twelfth fare. The Southern Pacific Company's rates from Portland, Ogden and El Paso are one fare.

All tickets sold at these points carry five coupons of admittance to the Mid-Winter Fair. 